"The domestic resource gap and current transaction deficit in Indonesia in 20102014"

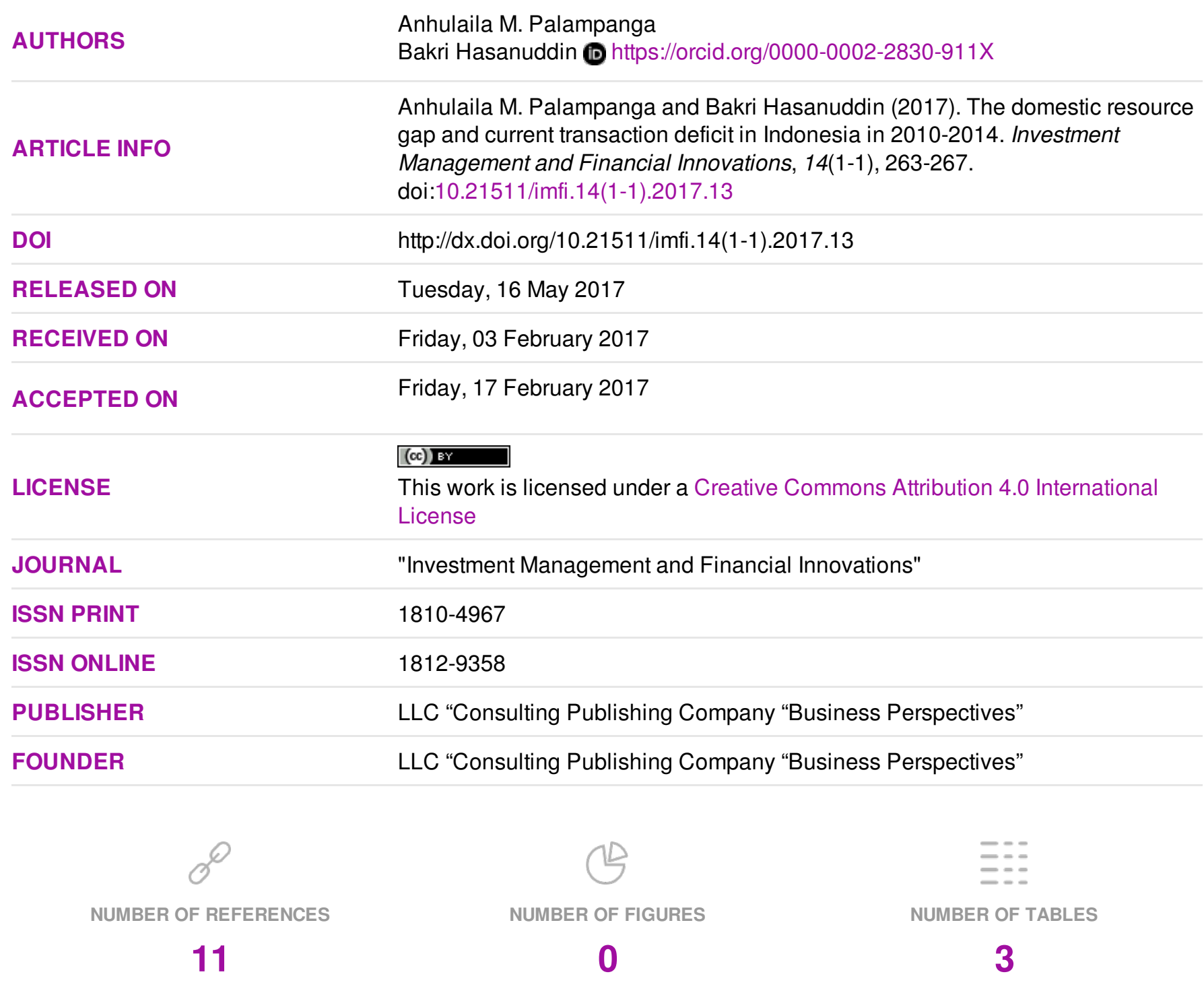

(C) The author(s) 2023. This publication is an open access article. 
Anhulaila M. Palampanga (Indonesia), Bakri Hasanuddin (Indonesia)

\title{
The domestic resource gap and current transaction deficit in Indonesia in 2010-2014
}

\begin{abstract}
The purpose of this study is to determine the relationship between domestic financial resource gaps and current account balance in Indonesia by using data from 2010 to 2014. Gaps in the domestic economy are classified into three types: 1) the domestic absorptive capacity of the national income gap (GNP), 2) gross national savings and investment gap, 3) private sector gap (private saving minus private investment), and public sector gap (tax minus government spending). By using a concept of open economy that is described in a theoretical framework, the study results show that: 1) the gap absorption of domestic and GNP, 2) the gap between gross national savings and gross national investments, 3) the gap in private sector and government sector resulting in deficit in the current account during Indonesia on 2010-2014 periods.
\end{abstract}

Keywords: current account balance, national income, domestic absorption, savings, investments.

JEL Classification: E2.

Received on: $3^{\text {th }}$ of February, 2017.

Accepted on: 17 $7^{\text {th }}$ of February, 2017.

\section{Introduction}

Limitations of a country fulfilling all its needs independently, have led to efforts that make the international economic transactions, whether in the form of transactions of goods, services, and capital. To determine the position of a country in international economic transactions, the balance of payments was invented, which systematically summarizes all economic transactions with foreign countries during a given period of time expressed in money.

Trade balance records the exports and imports of goods, services account records exports and imports of services, as well as unilateral transfers, among others, noted the payment of interest on capital flow in and out, determine the current account position of a country, whether surplus or deficit. Surplus shows the value of exports (revenues from abroad) is greater than the imports (payments abroad), while the deficit shows the opposite. However, as foreign economic transactions of a country are strongly influenced by the economic conditions in the country, the current account position is also influenced by the difference between gross domestic investments and gross national savings. By involving the public sector through including the taxes and transfer payments to the community, the current account position can be also associated with private savings and investment gap, or the difference between tax revenues through government spending.

(C) Anhulaila M. Palampanga, Bakri Hasanuddin, 2017. Anhulaila M. Palampanga, Economic and Development Studies (IESP), Faculty of Economics, Tadulako University, Indonesia. Bakri Hasanuddin, Economic and Development Studies (IESP), Faculty of Economics, Tadulako University, Indonesia.

This is an Open Access article, distributed under the terms of the Creative Commons Attribution 4.0 International license, which permits unrestricted re-use, distribution, and reproduction in any medium, provided the original work is properly cited.
According to Indonesian Bank Report in 2015, the 2010-2014 showed that a surplus of 5,146 million US \$ in 2010 fell to 1,686 million US \$ in 2011, and the slump continued until it reached a deficit of 26,232 million US \$ in 2014. Although during the observation period the balance on goods (the value of exports and imports of goods) and the secondary income (net income from unilateral transfers) shows the value that is always positive, but postal services balance and primary income shows the opposite situation that the deficit has greater amount.

The deficit of services account increased from US \$ 9,791 million in 2010 to US \$ 10,533 in 2014. Similarly, the primary deficit income also showed an increase of US \$ 696 million in 2010 to US \$27,822 million in 2014. The deficit is happening, when both these posts are not able to offset the surplus on the trade balance and the balance of secondary income resulting is transactions, tends to weaken even being a deficit in the last three years of the observation period. Post primary deficit has constantly grown during the period of 2010-2014, which indicates that the amount of interest payments on foreign loans by the government and private sector is greater than the interest payments received by domestic economic actors who make investments abroad.

\section{Research methodology}

Studies in this article use annual data of the Indonesian economy during the 2010-2014 period. The types of data are: 1) Real Gross Domestic Product (GDP), 2) Government budget, and 3) Balance of Payments. These data were sourced from: Statistics of Indonesia (Statistic Yearbook of Indonesia), Statistic Center of Indonesia, 4) Indonesia Balance of Payments Report, Bank Indonesia. In order to solve the problem that has 
been described previously, the annual average growth formula and contributions are used as follows: the annual average growth:

$Y_{n}=Y_{0}(1+r) n-1 \ldots$,

where, $Y_{n}$ - value variable in the year $n ; Y_{0}$ - value variable in the year $0 ; N$-number of years; $r$-rate of growth in average variable every year.

Equation (1) is used to calculate the growth rate on average of each year for the variables: 1) current account balance, 2) GNP, 3) private consumption, 4) private investment, 5) public expenditure, 6) absorption domestic, 7) gross national savings, 8) gross national investments, 9) gaps in private sector (private savings minus private investments), 10) gaps in government sector (taxes minus government spending).

Contributions:

$K_{V 1}=\frac{V_{1}}{V} \times 100$,

where, $K_{V 1}$ - contributions of variable 1 to variable; $V_{1}$ - value of variable $1 ; V$ - variable data.

Equation (2) is used to calculate contributions: 1) $\mathrm{CAB}$ against GNP, 2) private consumption to GNP, 3) private investment to GNP, 4) government spending to GNP, absorption of domestic against GNP, 5) gross national savings against GNP, 6) gross national investments against GNP, 7) gaps in private sector to the GNP, 8) gaps in government sector to the GNP.

\section{Results and analysis}

Based on the macro-picture of international economics of Indonesia, and following the theoretical framework as described above, this section will analyze the factors that resulted in the current account deficit of the Indonesian balance of payments such as: production and domestic absorption gap, savings and investment gap, and government sector gap.

\section{Domestic absorption and current account balance}

Gross national product is the total production of goods and services produced by residents of a country for a certain period by looking at the clean production factor from abroad that is commonly formulated as follows:
$Y=C+I+G+X-M$,

where, $Y$ - GNP; $C$ - private consumption expenditure; $I$ - private investments; $G$ government expenditure; $X$ - export of goods and services; $M$ - import of goods and services.

There is a tendency on the GNP formula above. If GNP rises, then private consumption, private investment, and government spending will also rise. This condition is also experienced by Indonesia, even during the 2010-2014 periods; all of the domestic absorption growth exceeded the GNP growth.

During 2010-2014 the total domestic absorption experienced an annual average growth of 12.83 percent: private investments -13.45 percent, 12.68 percent of private consumption and government spending amounted to 11.48 percent. Meanwhile at the same period GNP grew by 11.69 percent. GNP growth less than the growth of the total domestic absorption resulted, that the gap between the total domestic absorption and GNP widened. In 2010 the absorption of domestic economic agents by 101.2 percent of national production capability (GNP). This absorptive capacity continued to increase to 105.3 percent in 2014.

The widening gap between domestic absorptive capacity with the ability of national production can be observed also by indicators of current account balance $(\mathrm{CAB})$ which indicated, that the value of the deficit continued to increase. In 2010 the current account deficit was 1.2 percent of GNP, the value of this deficit increased to 4.5 percent in 2012 and continued to grow to 5.3 percent in 2015. The increase of current account deficit means that extremely large amount of foreign exchange reserves would be necessary to cover the excess of imports over exports of goods and services, it means the required capital is sufficient to cover the current account deficit.

Table 1 shows that the structure of GNP during 2010-2014 is still dominated by the household sector spending, with a contribution of 58.5 percent in 2010 increased to 60.6 percent in 2014. Similarly, the private investments at the same period increased from 33.2 to 35.4 percent. While the contribution of government spending, decreased relatively insufficient from 9.4 to 9.3 percent.

Table 1. National income, domestic absorption, and Indonesian current account balance, 2010-2014 (billion rupiah)

\begin{tabular}{|c|l|c|c|c|c|c|c|}
\hline Number & \multicolumn{1}{|c|}{ Indicator } & 2010 & 2011 & 2012 & 2013 & 2014 & Growth/year \\
\hline 1 & $\mathrm{CAB}$ & 72.915 .4 & 112.142 .1 & 361.872 .6 & 445.757 .7 & 520.436 .0 & 63.45 \\
\hline 2 & $\mathrm{GNP}$ & 6.265 .883 .0 & 7.202 .294 .4 & 7.987 .733 .0 & 8.806 .179 .7 & 9.751 .710 .0 & 11.69 \\
\hline 3 & $\mathrm{CN}^{*}$ & 3.66 .157 .0 & 4.204 .388 .8 & 4.762 .892 .5 & 5.369 .925 .9 & 5.913 .873 .4 & 12.68 \\
\hline 4 & $\mathrm{IS}^{*}$ & 2.083 .358 .5 & 2.441 .047 .1 & 2.853 .443 .6 & 3.054 .713 .7 & 3.451 .346 .3 & 13.45 \\
\hline
\end{tabular}


Table 1 (cont.). National income, domestic absorption, and Indonesian current account balance, 2010-2014 (billion rupiah)

\begin{tabular}{|c|l|c|c|c|c|c|c|}
\hline Number & \multicolumn{1}{|c|}{ Indicator } & 2010 & 2011 & 2012 & 2013 & 2014 & Growth/year \\
\hline 5 & GN & 587.282 .9 & 669.000 .6 & 733.269 .4 & 827.297 .8 & 906.926 .3 & 11.48 \\
\hline 6 & DA & 6.338 .798 .4 & 7.314 .436 .5 & 8.349 .605 .5 & 9.251 .937 .4 & 10.272 .146 .0 & 12.83 \\
\hline 7 & CAB/GNP & $(1.2)$ & $(1.6)$ & $(4.5)$ & $(5.1)$ & $(5.3)$ & \\
\hline 8 & CN*/GNP & 58.5 & 58.4 & 59.6 & 61.0 & 60.6 \\
\hline 9 & I $*$ GNP & 33.2 & 33.9 & 35.7 & 34.7 & 35.4 \\
\hline 10 & GN/GNP & 9.4 & 9.3 & 9.2 & 9.4 & 9.3 \\
\hline 11 & AD/GNP & 101.2 & 101.6 & 104.5 & 105.1 & 105.3 & \\
\hline
\end{tabular}

Source: Indonesia Statistics (Statistic Yearbook of Indonesia), 2014, 2015 BPS Jakarta

Notes: $\mathrm{CAB}$ (current account balance), GNP (gross national product), $\mathrm{CN}^{*}$ (CN + statistical adjustments), IS (IS changes in inventories), GN (government expenditure), DA (domestic absorptive capacity).

In the future, household consumption is predicted to be the dominant sector in stirring the domestic economy. This is due to continued improvement in economic growth will have a positive impact on per capita income and purchasing power. Aside from being a source of economic growth, increasing household consumption is also expected to have a negative impact on the current account through increased imports. Therefore, wherever possible increase in imports offset by an increase in exports in the same proportion, not to negatively affect the availability of foreign exchange reserves.

3.1. Savings, investments and current account balance. Table 2 shows the gap between savings and investment demand. During 2010-2014, the number of gross national savings increased from
$2,092,619.2$ billion rupiahs in 2010 to $2,643,546.1$ billion rupiahs in 2012, and increased again to 3,136,710.3 billion rupiahs in 2014. Meanwhile, investment demand has continually larger amounts of 2,165,534.5 billion rupiahs in $2010 ; 3,005,418.6$ billion rupiahs in 2012, and 3,657,146.3 rupiahs in 2014. During 2010-2014, the average annual growth of investments also exceeded the savings, i.e. 14.00 percent for investments and 10.65 percent for savings. The growth of gross national investments can't be offset by growth in gross national savings that have a negative impact on the current account. The current account deficit continued to rise from $72,915.4$ billion rupiahs in 2010 to $361,872.6$ billion rupiahs in 2012, and continued to increase to $520,436.0$ billion rupiahs in 2015 .

Table 2. The gross national savings, gross national investments and Indonesian current account balance, 2010-2014 (billion rupiah)

\begin{tabular}{|c|l|c|c|c|c|c|c|}
\hline Number & \multicolumn{1}{|c|}{ Indicator } & 2010 & 2011 & 2012 & 2013 & 2014 & Growth/year \\
\hline 1 & $\begin{array}{l}\text { CAB =TNB - GROSS } \\
\text { NATIONAL INVESTMENTS }\end{array}$ & $(72,915.4)$ & $(112,142.1)$ & $(361,872.6)$ & $(445,757.7)$ & $(520,436.0)$ & 63.45 \\
\hline 2 & $\begin{array}{l}\text { GROSS NATIONAL } \\
\text { SAVINGS = YN - CN - CNG }\end{array}$ & $2,092,619.2$ & $2,464,759.0$ & $2,643.546 .1$ & $2,793,320.1$ & $3,136,710.3$ & 10.65 \\
\hline 3 & $\begin{array}{l}\text { GROSS NATIONAL } \\
\text { INVESTMENT = IN + ING }\end{array}$ & $2,165,534.5$ & $2,576,901.1$ & $3,005,418.6$ & $3,239,077.7$ & $3,657,146.3$ & 14.00 \\
\hline 4 & TNB/GNP & 33.4 & 34.2 & 33.1 & 31.7 & 32.2 & 37.5 \\
\hline 5 & INB/GNP & 34.6 & 35.8 & 37.6 & 36.8 & 2 \\
\hline
\end{tabular}

Source: Indonesia Statistics (Statistic Yearbook of Indonesia) 2014, 2015 BPS Jakarta (processed).

Notes: CAB (current account balance), Gross national savings, YN = GNP (gross national product), CN (private consumption), CG (government consumption), gross national investments, IN (private investment), ING (government investments).

Savings and investments gap can also be observed by the proportion of savings and investments in GNP. Table 2 shows that the proportion of investments is always greater than the proportion of savings. In 2014 comparatively with 2010 the proportion of investments increased from 34.6 percent to 37.5 percent, while the savings decreased from 33.4 percent to 32.2 percent. Through this approach, the effort to reduce the current account deficit can be done by suppressing the gross national investments and/or increasing gross national savings. Slowing investment activity would have a negative impact on the national economy at the macro level, in particular, on employment, economic growth, government revenues in the form of taxes, and at a later stage can even adversely affect exports. Therefore, efforts to increase national savings through reduction of consumption, either in the form of household consumption and government consumption, especially for imported consumer goods, are considered to be more appropriate in an effort to reduce the gap of investments and savings as well as to improve the current account deficit. 
3.2. Private sector, government sector and current account balance. This section will explain about the identic deficits, they are conditions that indicate the private sector deficit, in this case the difference between private savings and investments and the government budget deficit, it is about the difference between government revenue on taxes and government spending.

Table 3. Private savings, private investments, tax, expenditures and current account balance in Indonesia in 2010-2014 (billion rupiahs)

\begin{tabular}{|c|l|c|c|c|c|c|c|}
\hline Number & \multicolumn{1}{|c|}{ Indicator } & 2010 & 2011 & 2012 & 2013 & 2014 & Growth/year \\
\hline 1 & $\mathrm{CAB}$ & $(72,915.4)$ & $(112,142.1)$ & $(361,872.6)$ & $(445,757.7)$ & $(520,436.0)$ & 63.45 \\
\hline 2 & $\mathrm{SN}-\mathrm{IN}$ & $(433,781.5)$ & $(544,303.5)$ & $(939,165.2)$ & $(1,143,648.9)$ & $(1,279,290.7)$ & 31.05 \\
\hline 3 & $\mathrm{TX}-\mathrm{GN}$ & $360,866.1$ & $432,161.4$ & $577,292.6$ & $697,891.2$ & $758,854.7$ & 20.42 \\
\hline 4 & $(\mathrm{SN}-\mathrm{IN}) /(\mathrm{GNP})$ & $(6.9)$ & $(7.6)$ & $(11.8)$ & $(13.0)$ & $(13.1)$ & \\
\hline 5 & $(\mathrm{TX}-\mathrm{GN}) /(\mathrm{GNP})$ & 5.8 & 6.0 & 7.2 & 7.9 & 7.8 & \\
\hline
\end{tabular}

Source: Statistics Indonesia (Statistic Yearbook of Indonesia) 2014, 2015 BPS Jakarta (processed).

Notes: CAB (current account balance), SN (private savings), IN (private investments), TX (tax), GN (government spending), GNP (gross national product).

Identic deficits are expected to negatively affect the position of the current account deficit. Table 3 demonstrates, that in 2010-2014 the gap of savings and private sector investments showed increasing trend of deficit of 433,781.5 billion rupiahs in 2010, rising to $939,165.2$ billion rupiahs in 2012 and continued to increase to $1,279,290.7$ billion rupiahs in 2014. The increase in savings deficit and investments in the private sector has been accompanied by the growth of current account deficit that was $72,915.4$ billion rupiahs in 2010 then became $361,872.6$ billion rupiahs in 2012 and increased to 520,436.0 billion rupiahs in 2014 .

The deficit growth in private sector can be observed also as the private sector deficit ratio to GNP with a value that is increased from 6.9 percent in 2010 to 11.8 percent in 2012 and to 13.1 percent in 2014. While the surplus on the government sector with the tax value minus government spending (TX - GN) becomes positive, it is estimated that the $\mathrm{GN}$ value in the national income table (GNP) does not yet reflect the total actual government expenditure. There are other types of government expenditures which included in GN (GN value is lower than it should be) and causes the tax value minus the positive government spending.

In order to explain the sources of funds to cover country's current account balance deficit we used the approach based on open economy concept. As it was mentioned in literature review, inequalities of domestic sources are divided into three groups: 1) production and domestic absorption gaps, 2) gross national savings and investments gap, and 3) private sector gap (private savings minus private investments) and government sector gap (tax minus expenditure government).

By using the Indonesian GNP data through expenditure according to current prices in 20102014, it can be shown that the gap in domestic production and domestic absorptive capacity of the economy has resulted in large current account deficits. The current account deficit was also caused by the lower gross national savings compared with the gross national investments.

Chenery (Jhingan, 2013) stated that savings and investments gaps on the one hand, and the foreign exchange gap on the other hand, are an obstacle for underdeveloped countries in their development. Foreign financial assistance is considered as a way to reduce the gaps in economic growth achievement that has been targeted.

The current account deficit is also caused by the gap that occurs in private sector, i.e. the excess of private investments compared with private savings. Lower private savings can be caused by people's lifestyles that tend to be consumptive, which will ultimately result in low investment funds, sourced from domestic savings. Meanwhile for the gaps in the governmental sector based on taxes and government expenditures, it appears there is a surplus in the public sector, that means that amount of government spendings is lower than the tax revenues. In accordance with the theoretical framework, calculation of government sector balance is using government expenditure data (GN) on the national income table which is estimated to be lower than expected, causing a surplus on the government sector. The balance of the government sector will be a deficit if the government expenditures variable $(\mathrm{GN})$ is derived from the state budget, because the data version of the state government spending budget is greater than the government spendings data version of the national income.

\section{Conclusion}

Based on the results and analysis of the research we can make the following conclusions: 
1. During 2010-2014, the absorption of domestic economic factors such as household consumption, investments and government spendings that exceed the ability of national production (GNP) has a negative impact on the current account balance of Indonesia, i.e. the deficit of 72,915.4 billion rupiahs in 2010 increased to 520,436.0 billion rupiahs in 2014 .

2. The current account deficit was also caused by the gap between gross national savings and investment gap. In 2010, gross national savings was 2,092,619.2 billion and increased to $3,136,710.3$ billion rupiahs in 2014 . Meanwhile, the gross national investments always exceeded the gross national savings. $2,165,534.5$ billion rupiahs in 2010 increased to $3,657,146.3$ billion rupiahs in 2014 . The gap between gross national savings and gross national investments can be also demonstrated by the ratio of each variables to the GNP. In 2010 the ratio of gross national savings to GNP was 33.4 percent and a slight decrease to 32.2 percent was in 2014. Meanwhile, the proportion of gross national investments to GNP at the same period was 34.6 percent and 37.5 percent.

3. The current account deficit can also reflect a deficit in the private or government sectors. Deficit in private sector (private savings minus private investments) increased from 433,781.5 billion rupiahs in 2010 to $1,279,290.7$ billion rupiahs in 2014.

4. By using the tax approach minus government spending which is used to calculate the government sector deficit, the surplus value obtained $360,866.1$ billion rupiahs in 2010 increased to $758,854.7$ billion rupiahs in 2014 . This surplus result is estimated because the data is using the government expenditure data on national income based on the usage that has a lower value than it should be and causing a surplus on the government sector.

\section{References}

1. BPS Indonesia. (2015). Statistik Indonesia, Badan Pusat Statistik Indonesia, Jakarta.

2. BPS Indonesia. (2014). Statistik Indonesia Statistc Yearbook of Indonesia, Badan Pusat Statistik Indonesia, Jakarta.

3. BPS Indonesia. (2014). Laporan Neraca Pembayaran Indonesia, Bank Indonesia, Jakarta.

4. Cavallo, Michele. (2005, February). Government Consumption Expenditures and The Current Account. Working Paper Series, Federal Reserve Bank Of San Francisco.

5. Erdogan, Seyfettin. (2014). The Relationship between the Budget Deficit and Current Account Deficit in Turkey. Emerging Market Journal, University Pittsburgh Press.

6. Jhingan, M. L. (2013). Ekonomi Pembangunan dan Perencanaan, PT Raja Grafindo Persada, Jakarta.

7. Merza, Ebrahim. (2012, April). The Relationship Between Current Account and Government Budget Balance: The Case of Kuwait. International Journal of Humanities and Social Science, USA.

8. Nafsiger, Wayne, E. (1997). The Economics of Developing Countries. Prentice-Hall, Inc., New Jersey.

9. Tuck Cheong Tang. (2013). Twin Deficits: An Alternative Framework From General Equilibrium Perspective With U.U. Results, Discussion Paper 41/13, Department of Economics, Business and Economics Monash University.

10. Van Bon, Nguyen. (2014). Current Account and Fiscal Deficits Evidence of Twin Divergence from Selected Developing Economies of Asia. Southeast Asian Journal of Economics, 2(2), 33-48.

11. Widodo, Susena, T. (Januari, 1990). Indikator Ekonomi Dasar Perhitungan Perekonomian Indonesia. Penerbit Kanisius, Yoyakarta. 